\title{
Complex hydrogeological modeling of multifunctional artificial recharge options of the Great-Forest Park in Debrecen, Hungary
}

\author{
P. Szücs \& T. Madarász \\ Department of Hydrogeology and Engineering Geology, \\ University of Miskolc, Faculty of Applied Earth Science and Engineering, \\ Hungary
}

\begin{abstract}
A complex hydrogeological study was carried out in the framework of the CIVAQUA program organized by the Trans-Tisza Region Environmental and Water Authority to provide the multifunctional artificial recharge of Great-Forest in Debrecen, East-Hungary. Due to several decades of overproduction of groundwater resources, the groundwater heads below the famous park area in the heart of the city has decreased to $12-14 \mathrm{~m}$, causing significant destruction of the valuable and protected surface ecosystem. The groundwater model of the investigated area was utilized to investigate several technical solutions in order to solve the severe water quantity deficit of the park. The source of the infiltration recharge is provided from near-site surface water bodies, which raises inevitable issues concerning the groundwater quality. In addition to the urgent need for finding appropriate recharge alternatives, the environmental authorities are aware of the slow mobilization of a complex hydrocarbon groundwater contamination from an adjacent industrial complex of the city. The contaminant plume was proved to evolve in the direction of the waterworks wells. The hydrodynamic and transport modeling aided planning has to give answers to several questions of a complex groundwater quality and quantity problem of this major city in Hungary. The modeling aided concept wanted to find a carefully designed artificial recharge strategy that serves the reconciliation of ecological and drinking water demand, but at the same time forming a hydrodynamic barrier in the way of the contamination plume.
\end{abstract}

Keywords: hydrodynamic and transport modeling, overproduction, artificial groundwater recharge, groundwater quality problems. 


\section{Rationale and background}

Debrecen is a major city in Eastern-Hungary with a population of 220,000 people. One of the main natural attractions of the city is the so-called Great Forest, located in the heart of the city on an area of appr. 11000 hectare. The inhabitants of the city carefully safeguard the prestige of their park, however significant damage has been observed in the condition of the forest during the last decades. The city water works has been operating one of its major units in the vicinity of the park since the beginning of the $20^{\text {th }}$ century. The significant overproduction resulted in more than 10 meters of drop in the shallow groundwater head during the last 30 years, causing considerable damage in the valuable ecosystem. To improve the current condition artificial recharge systems are designed and modeled to find the best solution.

In addition to the urgent need for finding appropriate recharge alternatives, the environmental authorities are aware of the slow mobilization of a complex hydrocarbon groundwater contamination from an adjacent industrial complex of the city. The contaminant plume was proved to evolve in the direction of the waterworks wells. The hydrodynamic and transport modeling aided planning has to give answers to several questions of a complex groundwater quality and quantity problem of this major city in Hungary. The modeling aided concept wanted to find a carefully designed artificial recharge strategy that serves the reconciliation of ecological and drinking water demand, but in the same time forming a hydrodynamic barrier in the way of the contamination plume.

\section{Geological setting and geometry of the study area}

The Quartier sediment series of the study can be described by three major aquifer groups: lower Pleistocene "waterworks" aquifer, middle Pleistocene aquifer and the upper, unconfined aquifer that includes the shallow aquifer as well. These Quartier layers are covered with a fine silty and clayey sequence. The aquifers are separated from each other by interbedded clay and clayey sand layers, however the three systems are not isolated from each other hydraulically, there is a significant hydraulic interaction between them through existing hydraulic "windows".

The drinking water source of the city of Debrecen was shifted from surface water to groundwater resources in the early 1900s. Until the 1950s this change did not cause observable difference in the groundwater system's balance. Significant depression of the potentiometer head of the deeper aquifers can be traced from the 1970s. The effect was the most dramatic around the wells of the No. 2 waterworks. The water production of these wells is based on $90-120 \mathrm{~m}$ deep layers. The dramatic depression of these deeper aquifers resulted in a 7-13 meter subsidence of the shallow groundwater head in the Great Forest area. The significant depression of the shallow groundwater table and the resulting unfavorable water balance are closely related to the destruction of the valuable forest and the surface ecosystem. 
The hydrodynamic model of the area was compiled using the Processing MODFLOW for Windows 7.0 (PMWIN Pro) modeling package, particularly the MODFLOW 2000 module of the PMWIN system. A quasi three-layered, 3D geometry of the model was sufficient to understand the flow system of the groundwater bodies of the study area, and the effect of the designed recharge system. The delineation of the study area was given so that $100 \mathrm{~m} * 100 \mathrm{~m}$ grid network expanded to $12 \mathrm{~km} * 16 \mathrm{~km}$ in size, the grid cells were refined to $25 \mathrm{~m}^{*} 25 \mathrm{~m}$ in the vicinity of the waterworks wells (Figure 1). After the initial steady state model the transient flow model was also created for the site. The "Polyline Input" option of the software provided a very handy tool to simulate the linear structure of the surface infiltration facilities. The "up-stream" (NorthEast) and "down-stream" (South-West) boundary condition of the model was set as "constant head.
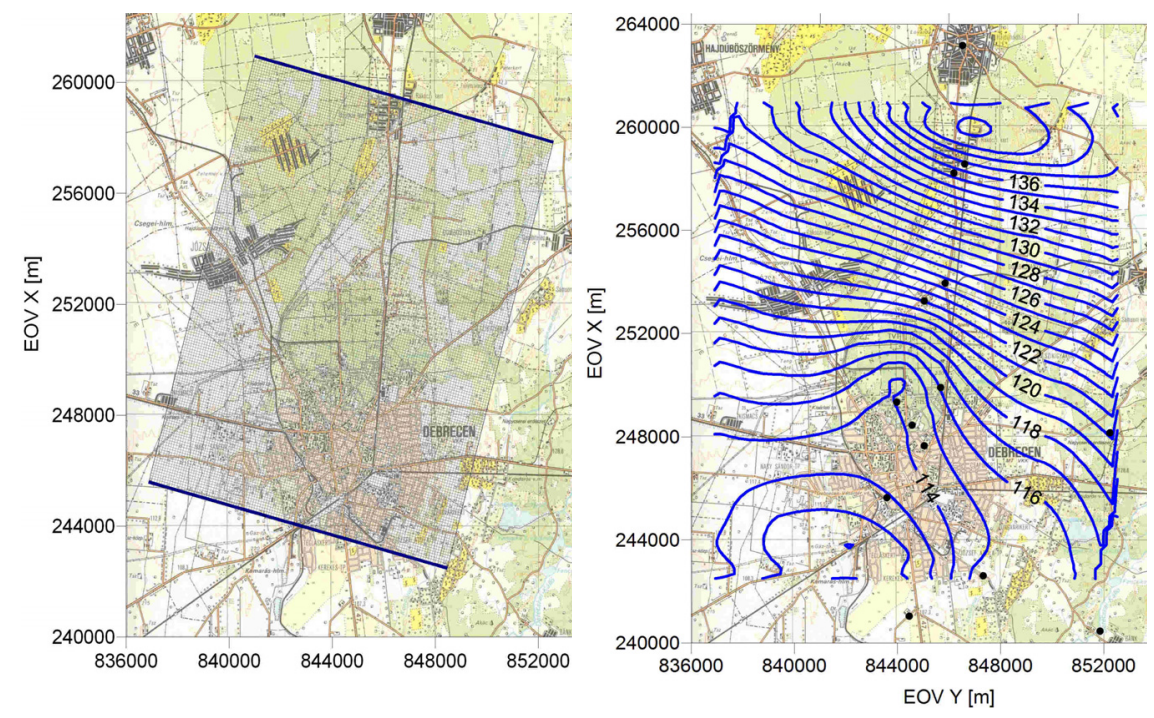

Figure 1: The grid cells distribution, area delineation of the model and the initial groundwater heads in meters above the Baltic see level.

\section{Technical alternatives of the artificial recharge}

The hydrodynamic model of the study was prepared to assess if the predefined target status of the groundwater system can be achieved by any technical solutions. The predefined target status of the Great Forest groundwater head is that it might be raised by 2-3 meters, which is the status of the early years of the $20^{\text {th }}$ century. When these conditions are met the desired ecological water demand is guaranteed by which the natural forests can be protected in the park. The study assessed three technical solutions as the possible ways of artificial recharge for the water: 
- installation of subsurface infiltration drains in the Great Forest

- $\quad$ use of an infiltration pond North of the Great Forest

- $\quad$ infiltration wells in the Great Forest

The study covered all three technical options, however in this paper only the major conclusions of the most favorable ones are mentioned due to the paper size constrains. Figure 2 shows the design and layout of the subsurface infiltration drains installed in the Great Forest.

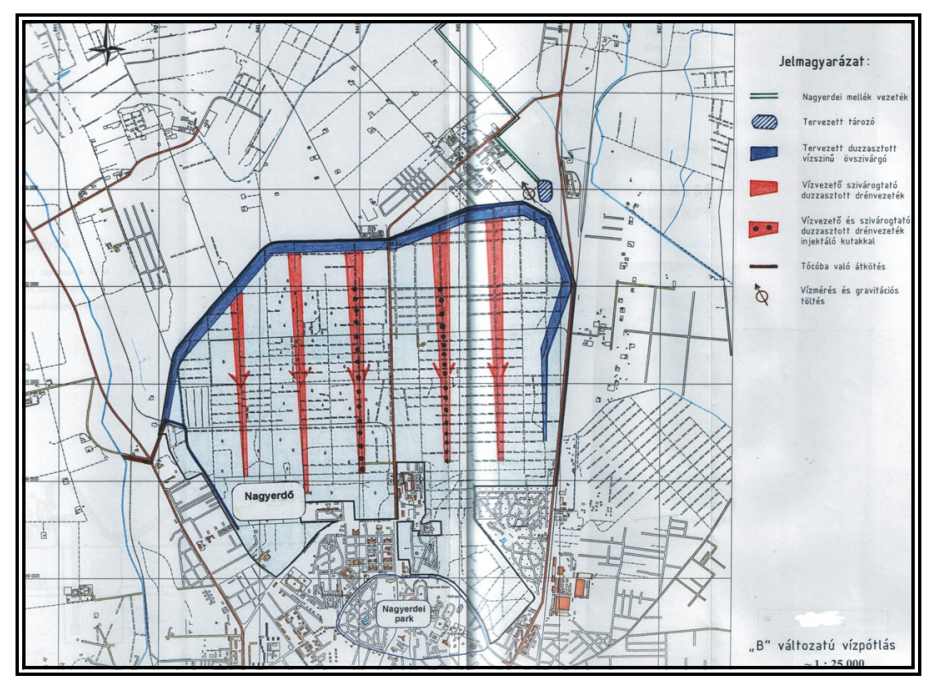

Figure 2: Arrangement of the subsurface infiltration drains in the Great Forest. The drains are installed in 2 meters depth below ground.

\section{The conclusions of the hydrodynamic modeling}

Four different model runs were done to evaluate the effect of the individual technical solutions. The four model runs contained the following considerations and technical and hydrogeological features:

1. Subsurface infiltration drains installed in the Great Forest with a constant infiltration rate of $3000 \mathrm{~m}^{3} /$ day, $1095000 \mathrm{~m}^{3} /$ year (Figure 3 ),

2. Simultaneous application of the infiltration drains and the infiltration pond, with an infiltration rate of $3000 \mathrm{~m}^{3} /$ day, $1095000 \mathrm{~m}^{3} /$ year, plus $5000 \mathrm{~m}^{3} /$ day, $1825000 \mathrm{~m}^{3} /$ year.

3 . Using the infiltration pond (only) with an infiltration capacity of $5000 \mathrm{~m}^{3} /$ day, $1825000 \mathrm{~m}^{3} /$ year.

4. Using the infiltration pond (only) with a controlled infiltration capacity of $1000 \mathrm{~m}^{3} /$ day, $3655000 \mathrm{~m}^{3} /$ year. 


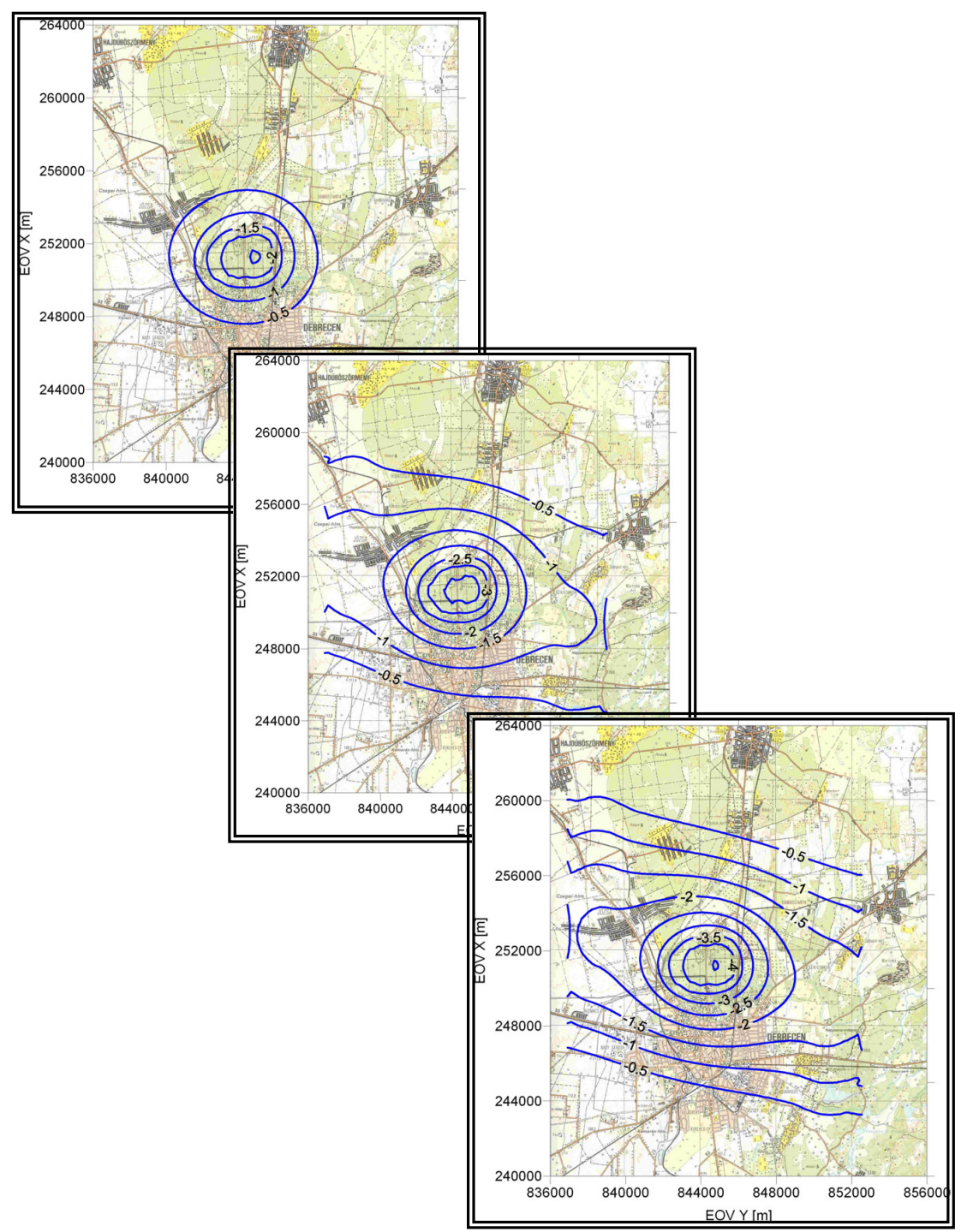

Figure 3: The change in hydraulic head in 5, 15 and 30 years time in the shallow groundwater below the Great Forest area, using infiltration drains with an infiltration capacity of $3000 \mathrm{~m}^{3} /$ day.

The results of the hydrodynamic modeling have proved that the target status of the groundwater heads (raising of the head with 2-3 meters below the Great Forest) can be reached by artificial infiltration solutions. When using the subsurface drains, with the infiltration capacity of $3000 \mathrm{~m}^{3} /$ day the desirable target status can be reached within a realistic time frame. In 5 years time 
2 meters rising of the head can be reached in the biggest part of the Great Forest, after 15 years more than 3 meters of head raising is observed. The permanent status of the head can be reached after 30 years. (Figure 3.)

The modeling exercise also proved that the infiltration pond located several kilometers from to the North from the Great Forest is not a real alternative for the recharge of the area. Although the effect of the infiltration reaches the Northern part of the park in 8-10 years time, but its magnitude is significantly less than that of the drains. In the same time in the very vicinity of the pond a considerable rising (1,5-3 meters) of water table is observed that can cause damage both to structures and agricultural activities in the area (Figure 4).

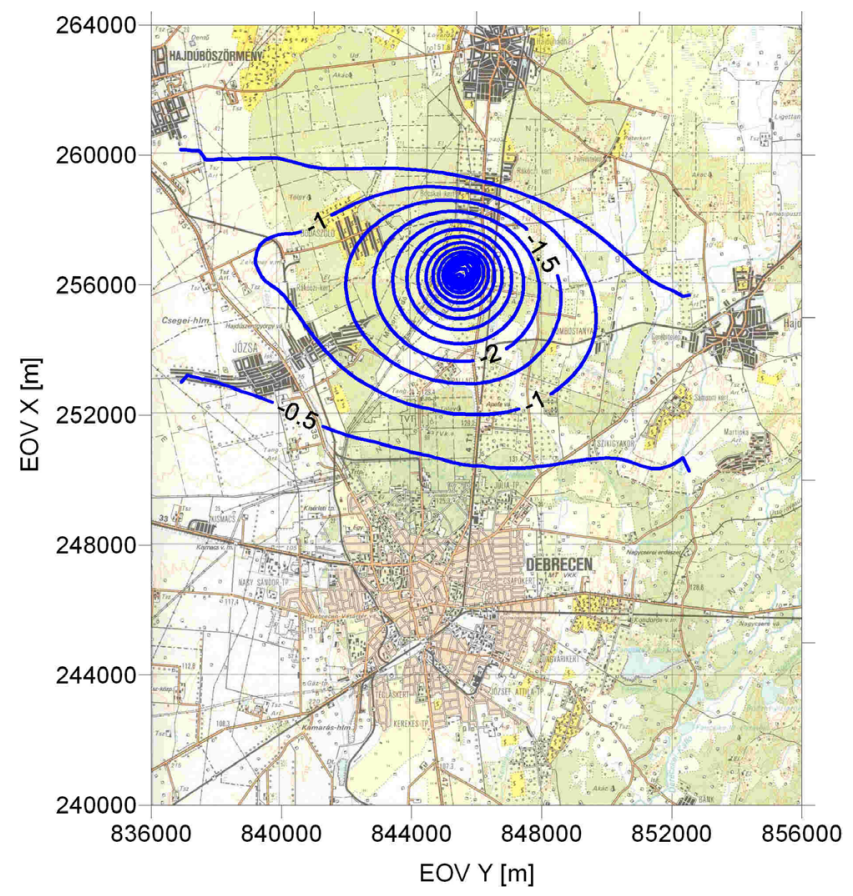

Figure 4: The effect of the infiltration pond featured by $5000 \mathrm{~m}^{3} /$ day infiltration rate. The raise of groundwater table is significant in the very vicinity of the pond but not so much in the Great Forest area.

\section{Groundwater quality issues}

The designed drainage system reaches the depth of 2 meters below surface. Considering the fact that the groundwater table is significantly lower than that, the discharged water has to migrate through the several meters thick unsaturated zone. This layer has a considerable capacity to buffer and clean the surface water used as a water source for the artificial discharge. This factor has an important 
role in adjusting the quality of the surface water to that of the more sensitive groundwater aquifer. In the same time this infiltration through the unsaturated zone might also have a negative effect. According to ecologist and specialists in forestry, those trees in the immediate vicinity of the drains might change their root structure and development, thus when the infiltration operation ceased these trees can be damaged due to the lack of water. To avoid these effects it is recommended by the study to more carefully analyze the option of infiltration wells instead of the infiltration drains.

It was not the task of the assessing team to evaluate the operation of the No 2. waterworks wells. However one must be aware that the obvious solution of the complex problem might be the closure of these wells, and searching for other water resource in the area. The main reason for this argument is not just its beneficial effect on the economical water demand, but also some of the warning statements of the local environmental authority. The cone of depression evolved because of the overproduction in the area has reached the site of a neighboring industrial and chemical facility and mobilized the complex hydrocarbon spill of the area.

\section{Acknowledgements}

The authors of this paper wish to thank the National Scientific and Research Fund (contract No: OTKA 048329), the GVOP programs (GVOP-3.1.1.-200405-0187/3.0, GVOP-3.1.1.-2004-05-0530/3.0) and the Bolyai János Research Scholarship for the support in implementing the study of this paper.

\section{References}

[1] K+K Osztrák-Magyar Környezetgazdálkodási és Közmütervező Kft.: Debreceni Nagyerdő többcélú vízpótlása. Részletes környezeti hatástanulmány. Összefoglaló. 2004. április, pp. 1-65.

[2] K+K Osztrák-Magyar Környezetgazdálkodási és Közmütervező Kft.: Debreceni Nagyerdő többcélú vízpótlása. Részletes környezeti hatástanulmány. Müszaki leírás. 2004. április, pp. 1-170.

[3] VIZITERV Consult Kft.: A Nagyerdő többcélú vízpótlása. Összefoglalás. Budapest - Nyíregyháza, 2001. november.

[4] Marton Lajos, Szanyi János: A talajvíztükör helyzete és a rétegvíz termelés kapcsolata Debrecen térségében. Hidrológiai Közlöny, 2000., 80. évf., 1.sz., pp. 3-13.

[5] M. Huysmans, T. Madarász, A. Dassargues: Risk Assessment of groundwater pollution using sensitivity analysis and worst case scenario analysis, Environmental Geology Publisher: Springer-Verlag $\mathrm{GmbH}$, ISSN: 0943-0105 (Paper) 1432-0495 (Online), Online published Febr. 22, 2006,

[6] Szanyi János: Felszín alatti víztermelés környezeti hatása a Dél-Nyírség példáján. $\mathrm{PhD}$ értekezés, Szeged, 2004., pp. 1-88. 
[7] Székely Ferenc: Az ÉK - Alföld regionális modellje. VITUKI, Budapest, 2003. november, pp. 1-63.

[8] Dr. Erdélyi Mihály (1979): A magyar medence hidrodinamikája (VITUKI közlemények 18),

[9] Halász Béla (1994): Felszín alatti vizekkel való gazdálkodás rétegzett hidrológiai rendszerekben (doktori értekezés),

[10] Juhász József (2002): Hidrogeológiai, Akadémiai Kiadó, Budapest,

[11] Tóth József (1995): Hydraulic continuity in large sedimentary basins. Hydrogeology Journal (3), no. 4., pp. 4-16.

[12] Szücs P., 2002: Inversion of pumping test data for improved interpretation. microCAD 2002, International Scientific Conference, University of Miskolc, A: Geoinformatics, pp. 107- 112, March 7- 8.

[13] Szücs P., Civan F., Virág M., 2006: Applicability of the most frequent value method in groundwater modeling. Hydrogeology Journal (2006), 14: pp. 31-43, Springer- Verlag.

[14] Szücs, P., Ritter Gy., 2002: Improved interpretation of pumping test results using simulated annealing optimization. ModelCARE 2002, Proceedings of the 4th International Conference on Calibration and Reliability in Groundwater Modeling. Prague, Czech Republic, 17- 20 June 2002. ACTA UNIVERSITAS CAROLINAE - GEOLOGICA 2002, 46 (2/3), pp. 238- 241. 